\title{
在宅医療のパラダイムの探求一爪白癬治療の取組を通して
}

\author{
鈴木順子, ${ }^{*, a}$ 今津嘉宏, ${ }^{a, b}$ 米田吉位, ${ }^{c}$ 山浦克典, ${ }^{d}$ 内田恵美子 $e$
}

\section{Paradigm Shift in the Quality of Regional Medical Care: Cooperative Treatment of Onychomycosis}

\begin{abstract}
Junko Suzuki, ${ }^{*, a}$ Yoshihiro Imazu, ${ }^{a, b}$ Yoshitaka Yoneta,${ }^{c}$ Katsunori Yamaura, ${ }^{d}$ and Emiko Uchida ${ }^{e}$ ${ }^{a}$ Kitasato University School of Pharmacy; 5-9-1 Shirogane, Minato-ku, Tokyo 108-8641, Japan: ${ }^{b}$ Shibadaimon Imazu Clinic; 1-1-14 Shibadaimon, Minato-ku, Tokyo 105-0012, Japan: ' $Y$ 's Clinic; 4-13-7 5F Minamiazabu, Minato-ku, Tokyo 106-0047, Japan: ${ }^{d}$ Faculty of Pharmacy, Keio University; 1-5-30 Shibakoen, Minato-ku, Tokyo 105-8512, Japan: and eJapan Home Care institute of Education and Research, Inc.; 3-15-7-102 Roppongi, Minato-ku, Tokyo 106-0032, Japan.
\end{abstract}

(Received May 17, 2017)

In a superaging society, the medical paradigm should include both less coverage of medical-care work flow by human resources and high-quality care for patients. Strategies such as establishing medical-care teams and community medicine systems mainly for home medical care should be implemented. However, a well-organized system for homebased medical treatment of elderly patients is not yet in place, as evidenced by the lack of care, problems with long-term polypharmacy resulting from visits to multiple healthcare providers, and declines in their physical strength. It is assumed that care might not be provided in association with treatment because planning based on the paradigm of "home medical care" has not been fully established. Therefore, in this study, we aimed to determine the "paradigm shift in home medical care" based on the treatment of onychomycosis. We also hoped to identify the types of medical support required to improve the general well-being of individuals and what needs to be done to ensure a high quality of life for patients. All those (including patients themselves) involved in patient care should together formulate a protocol for medical treatment and cooperate based on the role each can play. Although it may be difficult to maintain cooperation among healthcare workers, improvements in the medical quality of an entire region can be achieved by planning a life design including medical treatment for each patient.

Key words — home medical care; community medicine system; team medical care

\section{1. 超高齢社会における医療の問題}

1-1. 人口動態・分布の変動がもたらす問題 わが国が直面する超高齢・少子化社会では，総体 的人口減少に伴う大都市圈への人口集中と, 8 割以 上の国土の過疎化が予測されており，1)それは，地 方のコミュニティの衰退消滅をも示唆している.

さらに小家族化，高齢化により，物理的なコミュ

a 北里大学薬学部 ( ₹ 108-8641 東京都港区白金 5-9-1),

$b$ 芝大門いまづクリニック（テ105-0012 東京都港区芝 大門 1-1-14), ‘ワイズクリニック（テ106-0047 東京都 港区南麻布 4-13-7 5F), d慶應義塾大学薬学部（下1058512 東京都港区芝公園 1-5-30), e株式会社日本在宅ケ ア教育研究所（下106-0032 東京都港区六本木 3-15-7102)

*e-mail: suzukij@pharm.kitasato-u.ac.jp

本総説は, 日本薬学会第 136 年会シンポジウムS55 で 発表した内容を中心に記述したものである.
ニティの衰退のみならず，地方自治体の力の低下と インフラの衰退, そして地域の基盤となる自助力, 互助力の絶対的低下も懸念されている. 小家族化・ 高齢化は，実際には地方よりも大都市部で進んでお り, ${ }^{2)}$ 医療ニーズの更なる増大・長期化及び高密度 化が見込まれ，地方では逆に医療動線の著しい広域 化も課題となると予想される.

一方, 生産年齢人口層比率の圧縮傾向が続くと考 えられ, 現状のままでは医療提供力の低下は否めな い.

1-2. 現在の医療保障体系が孕む問題 国民医 療費の上昇の主たる要因は高齢者層人口比率の増大 であるとされ，生産年齢層の圧縮とあいまって，二 重の意味で生産年齢層に負担が集中していく構図は 明らかであり, 非常に問題視されている. 厚生労働 省「医療費の動向」（平成 26 年度版）によれば，既 
Table 1. The Relation between the Medical Expenses per Person and the Price Index

\begin{tabular}{c|c|c|c}
\hline \hline Year & $\begin{array}{c}\text { Price index } \\
\text { (percentage } \\
\text { change) }\end{array}$ & $\begin{array}{c}\text { Medical Expenses } \\
\text { per person younger } \\
\text { than 75 years } \\
\text { (percentage change) }\end{array}$ & $\begin{array}{c}\text { Medical Expenses } \\
\text { per person over } \\
\text { 75 years } \\
\text { (percentage change) }\end{array}$ \\
\hline 2008 & 102.1 & 84.1 & 95.8 \\
\hline 2009 & 100.7 & 99.7 & 97.9 \\
\hline 2010 & 100.0 & 100.0 & 100.0 \\
\hline 2011 & 99.7 & 103.1 & 101.7 \\
\hline 2012 & 99.7 & 104.6 & 101.6 \\
\hline 2013 & 100.0 & 106.2 & 102.9 \\
\hline 2014 & 102.8 & 108.2 & 103.3 \\
\hline
\end{tabular}

Insurance and other benefits from public medical insurance programs account for about $86 \%$ of National Health Expenditure. Thus, the change of national health expenses is hard to be affected by the change of prices. ${ }^{3,4)}$

に 1 人当たり医療費においても，平成 26 年度時点 で後期高齢者の場合，非高齢者の 4 倍以上であり， 高齢者層の医療ニーズの高さと受療密度の高さを窥 うことができる，その一方で，非高齢者の 1 人あた り医療費も上昇してきており，医療費の増大の原因 をただ，高齢者の増加のみに帰することはできない ということも明らかになっているが，その要因につ いて，筆者らの調査では，医療費の上昇と物価指数 に直接的な関係性は認められていない (Table 1). ${ }^{3,4)}$ いわゆる「医療費」の大半を占めるのが保険医療の 費用であって，保険という仕組みが現物給付方式で 運営されている以上，一定程度物価変動を緩衝する 作用があることから，直接的な関係性が認められな いことは了解できるものと考えられる．また，受療 率は低下傾向が続いており，同様に関連性はないと 考えられる. ${ }^{5}$ 部面別又は施設別の医療費の推移と いう切り口で検討した場合，薬局調剤関連医療費の 直線的な増加，病院における医療費の平成 9 年ごろ からの急激な増加などから，医療単価それ自体の増 大傾向と，その大きな要因が薬剤使用にある可能性 が浮上してくる. ${ }^{6}$

別途の調査によれば，薬剤費は保険改定のたびに カスケード状に上昇する傾向が明らかになつた. ${ }^{7)}$ なお，薬剤費の伸びは，技術料の伸びを凌駕してお り，医薬分業による医療の質の向上という意図とは 無関係に薬剂処方・調剂交付されている可能性が窥 われる. ${ }^{8)}$ 近時問題視されている多剂併用，長期連
用の病理は，保険医療制度そのものに内在してお り，それに対する抑制的思慮が働いてこなかったこ とが明らかである。

1-3. 医療保険制度における問題の様相「保 険改定のたびにカスケード状に上昇する薬剤費」と いう現実からは，かつて，医療供給の均てん化，公 平化，水準化を目指して構築された国民皆保険制度 が，超高齢・少子化という社会病理に対して制度的 あるいは構造的矛盾に陥つている可能性が示唆され る.

わが国の医療供給-受給の構造的骨格を形成して いる医療保険制度の特徵は，(1)社会保険方式による 運用，(2)原則的現物給付による療養の給付とされ る. ${ }^{9)}$

社会保険方式は，国民個々人の自助・互助関係の 形成に意義があり，所得等による保険料の傾斜もま た，社会的立場の異なる個々人が立場に応じて責任 を分担するという合理性がある，個々人における負 担のばらつきは，「皆保険化」によって母集団を大 きくすれば，平均化されるであろう。しかし，超高 齢・少子化という形で，母集団そのものに巨大なバ イアスが発生した場合，そもそもの前提が崩壊し， 逆に特定の層に負担が集中するという結果を生むこ とも考えられる.

さらに，超高齢・少子化という社会病理がもたら すものは，「備えるべきリスク」の規模や期間，コ ストの評価が不可能であるという点において，社会 保険システムの前提と真つ向から対立しかねない事 態であり，社会保険資産の先細りに拍車をかけるも のである.

現物給付による療養の給付の原則は，給付内容と 費用の関係が明確である，という点において，国民 にコスト意識を持たせる上で有用であり，これを もって医療へのフリーアクセスや進歩する医療の保 険への取入れ，医療の標準化，水準向上に益してき たのであるが，逆に保険で認められる範囲で過剩な 医療供給を常態化させ，それが医療の合理的標準で あるかのように定着させてきた可能性も否定はでき ない.

医療保険制度が，超高齢・少子化という社会病理 に対抗できず，制度矛盾を起こしているのは否めな い現実ではあるが，超高齢・少子化社会を乗り越 え，継続可能な医療提供体制を考える場合，医療保 


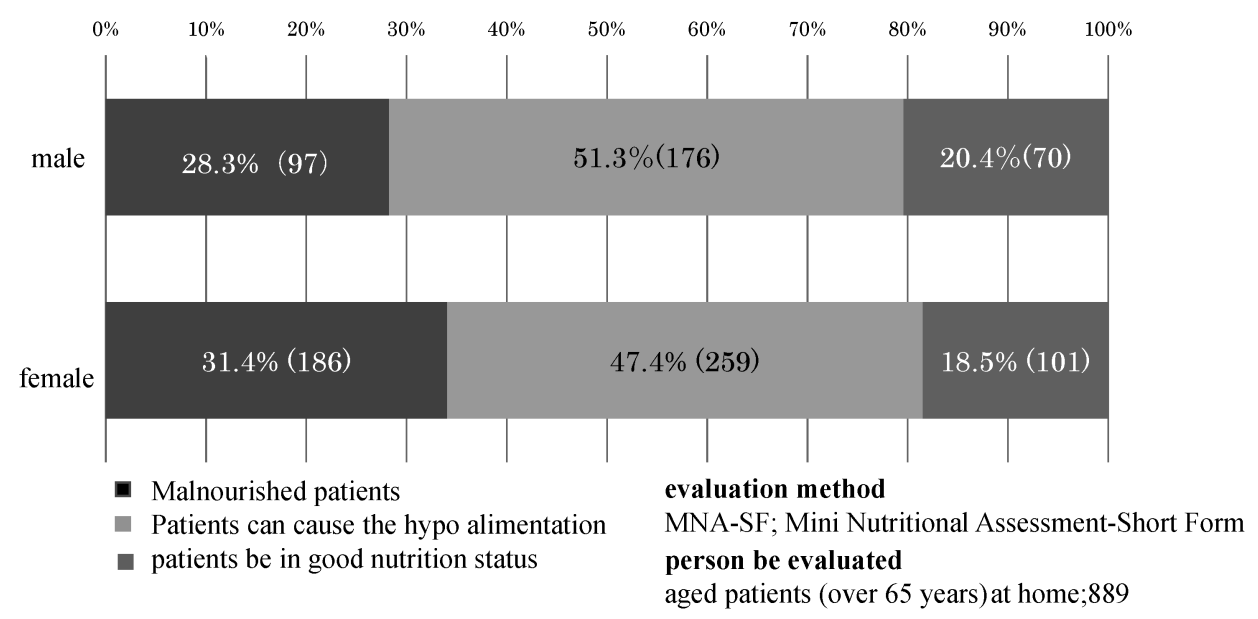

Fig. 1. Nourishment Evaluation for Aged Patients at Home with MNA-SF

Approximately $80 \%$ of aged patients at home, fall into the hypoalimentation state or the state with the fear of the hypoalimentation. ${ }^{13)}$

険制度を基盤としつつ，その他のサービスを柔軟に 提供できるための社会体制と運用を医療の水際から 考察する必要がある.

\section{2. 高齢居宅療養者の現状}

女性の平均寿命が 86.61 歳, 健康寿命が 74.21 歳, 男性では平均寿命 80.21 歳, 健康寿命 71.19 歳 と，それぞれ 12 年以上， 9 年以上の開きがあり， 人生の終わりの 10 年士を『人がましく生きて逝く』 という高齢者の理想とは裏腹な現実がある. ${ }^{10,11)}$

高齢居宅療養者の栄養状態と薬剂使用状況に関す る調査 ${ }^{12)}$ 及びその継承的分析研究13)では, 調査対象 の約 $80 \%$ Mini Nutritional Assessment-Short Form（MNA-SF）による栄養評価において『低栄 養又は低栄養の恐れあり』とされ (Fig. 1)，かつ 『食事も楽しみではない』とする率が $60 \%$ を超えて いる（Table 2)。さらに，同じ集団において服用さ れている 1 日当たりの薬剤数は算術平均でおよそ 6 剂，最大で 20 剂を超え，患者の activities of daily living (ADL) に影響を与えるであろう『中枢神経 作用薬』の投与率は薬物投与を受けている者の 62 \%に及ぶ（Table 3)。また, 薬剤使用と療養者の生 理状態・全身状態変化については, 上記調査研究の 継承的分析研究において, 高齢居宅療養者の 1 年間 における死亡転帰と利尿剂，下剂の長期連用の間に 統計上有意な関係が認められている（Table 4).

加えて, 同調査研究のローデータをフットケアに 焦点をあてて再集計したところ，（1）外用抗真菌薬 （水虫のくすりなど）が出ている患者は概算でおよ そ7\%おり，多くはこのほかになんらかのスキンケ
Table 2. Question to Aged Patients at Home "Do You Look Forward to a Meal?"

\begin{tabular}{|c|c|c|c|c|}
\hline \multicolumn{5}{|c|}{ Do you look forward to a meal? } \\
\hline & & No & Yes & Sum total \\
\hline \multirow{2}{*}{ Male } & The frequency & 191 & 127 & 318 \\
\hline & $\%$ & $60.1 \%$ & $39.9 \%$ & $100.0 \%$ \\
\hline \multirow{2}{*}{ Female } & The frequency & 335 & 194 & 529 \\
\hline & $\%$ & $63.3 \%$ & $37.7 \%$ & $100.0 \%$ \\
\hline \multirow{2}{*}{ Sum total } & The frequency & 526 & 321 & 847 \\
\hline & $\%$ & $62.1 \%$ & $37.9 \%$ & $100.0 \%$ \\
\hline
\end{tabular}

Person be evaluated; aged patients (over 65 years) at home; 847 . Evaluation method; Likert scale. Patients to answer that a meal is not a pleasure exceed $60 \%$. It cannot be said that the quality of life of aged patients at home is high. ${ }^{13)}$

ア用品を用いている.（2）内用抗真菌薬が出ている 患者で, ほかに呼吸器系などの感染症薬が出ていな い患者は概算でおよそ $0.4 \%$ ることがわかつた。

客観的には, 四肢の皮膚に真菌感染がありながら 中途半端な措置に終わっている，あるいは医療的方 針が定まらない患者の状態が見え，さらに治療べー スにさえ乗っていない患者も潜在的に多数存在する 可能性が高い.

港区と協働で経年実施している緩和ケア・在宅医 療に関する市民の意識調査 ${ }^{14)}$ では，市民の在宅医療 希望率が低下しつつあるとともに，その傾向が，介 護や在宅医療を直接間接に経験したことのある層で 著しいことが報告されており，市民が医療に対する 期待感と現実に対する失望感のはざまにあることが 浮き彫りとなっている. なお, 同調査において, 『在宅医療の担い手』としての薬剤師の認識率は調 
Table 3. The Situation of the Medicine Dosage for Aged Patients at Home

\begin{tabular}{l|c|c|c|c|c|c}
\hline \hline \multicolumn{6}{c}{ The number of prescription medicines for aged patients be conducted at home $(n=1073)$} \\
\hline The number of prescription medicines & 0 & $1-5$ & $6-10$ & $11-15$ & $16-20$ & $21-25$ \\
\hline The number of patients & 19 & 397 & 500 & 135 & 20 & 2 \\
\hline
\end{tabular}

$\langle 2\rangle$

The rate of the medicine acts on the central nervous system dosage for aged patients be conducted at home $(n=686)$

\begin{tabular}{l|c|c|c|c|c}
\hline Medicine category & Sleep inducing & $\begin{array}{c}\text { Antipyretic } \\
\text { analgesics }\end{array}$ & Anti-demantia & $\begin{array}{c}\text { For Parkinson's } \\
\text { disease }\end{array}$ & Anti-convulsant \\
\hline The number of patients & 84 & 77 & 58 & 46 & 37 \\
\hline Medicine category & Anti-anxiety & Anti-depressant & $\begin{array}{c}\text { Centrally acting } \\
\text { analgesic }\end{array}$ & Anti-psychotic & \\
\cline { 1 - 4 } The number of patients & 29 & 24 & 8 & 7 & \\
\hline
\end{tabular}

The number of the medicines taken per day is approximately six drugs in an arithmetical mean. Depending on a person, he (she) has been taken medicines higher than 20 drugs. The dosage rate of "the central nerve medicine" which will affect the ADL of the patient, amounts to $62 \%$ of patients. ${ }^{12)}$

Table 4. The Association between the Patients' Mortal Outcome within a Year and Prescription Medicines Given to Them

\begin{tabular}{|c|c|c|c|c|c|c|c|c|}
\hline & \multirow{2}{*}{ B } & \multirow{2}{*}{$\begin{array}{l}\text { Standard } \\
\text { error }\end{array}$} & \multirow{2}{*}{$\begin{array}{l}\text { Wald } \\
\text { statistic }\end{array}$} & \multirow{2}{*}{ Flexibility } & \multirow{2}{*}{$\begin{array}{c}p \\
\text { value }\end{array}$} & \multirow{2}{*}{$\begin{array}{l}\text { Odds } \\
\text { ratio }\end{array}$} & \multicolumn{2}{|c|}{$95 \%$ confidence interval } \\
\hline & & & & & & & Lower limit & Upper limit \\
\hline Sex & -.255 & .206 & 1.527 & 1 & .217 & .775 & .517 & 1.161 \\
\hline Age & .025 & .013 & 3.880 & 1 & .049 & 1.025 & 1.000 & 1.051 \\
\hline Central nerve medicine & .256 & .220 & 1.359 & 1 & .224 & 1.292 & .840 & 1.986 \\
\hline Diuretic & .514 & .218 & 5.583 & 1 & .018 & 1.672 & 1.092 & 2.516 \\
\hline Anti-demantia & -.515 & .358 & 2.074 & 1 & .150 & .597 & .296 & 1.204 \\
\hline Laxative & .452 & .220 & 5.109 & 1 & .024 & 1.572 & 1.062 & 2.327 \\
\hline Cardiovascular preparations & -1.029 & .208 & 24.449 & 1 & .000 & .357 & .238 & .357 \\
\hline Constant value & -3.264 & 1.098 & 8.866 & 1 & .003 & .038 & & \\
\hline
\end{tabular}

Target persons; mortal patients in a year (from 2012/10 to 2013/10), 135. Analysis method; Logistic regression analysis, "B" =regression coefficient. The patients had been taking laxative regularly, significantly had higher death rate 1.6 times than the whole. The patients had been taking diuretic regularly, significantly had higher death rate 1.7 times than the whole. The rambling dosage of laxative and diuretic for the long term might be in danger, because both medicines might affect the water receipt and disbursement of the body, and the ion balance of the body. ${ }^{13)}$

査開始時から一貫して低い.

このような地域医療のコアである在宅医療におけ

る，受療者の QOL，ADL が低い，薬剤負荷が高い などの統計的事実，患者を取り囲む介護者や家族の 失望感や重負担感が払拭できていない現実，あるい はそのような現実に対して医療提供者がともすれば 抱きがちな徒労感を解決し, よりよい地域医療のあ りかたを導くには，根本的なパラダイムシフトが急 務である。

\section{3. 地域医療のパラダイムシフト：地域包括ケア}

超高齢・少子化社会において想定される, 又は現 実化しつつある様々な病理的現象に対して，国は大
きく 2 つの系譜に基づく方針を提示している.

その 1 つが,「社会保障と税の一体改革」15)であ り, 特に医療・保健衛生・福祉（主に厚生労㗢省主 管の事業）部面では，大々的な改革が構想され，法 制化も進んでいる.

医療は国の社会保障制度に位置づけられるが，医 療の担い手は主に民間の医療機関・医療提供施設,

多くは民間人である医療従事者である，わが国の医 療は，国民皆保険制度に支えられながら，「医療の 発展」と「非営利性」の危ういバランスの下に運用 されてきたとも言えよう。

第 6 次医療法改正は,「医療提供体制の確保」を 
主眼としたものである. ${ }^{16,17)}$ 在宅医療を中心とする 地域医療体系の再編と確立，その対極にある病院の 医療機能の整理と強化，そして両者の連携による地 域全体としての医療の効率化と高度化，さらには, これらのシステム運用を介護・福祉を交えたより強 固なネットワーク構築によって遂行しようという企 図があり，これをいわゆる「地域医療構想」として， 医療関連の許可権限を持つ地方自治体がバックボー ンとなって，医療機関・医療提供施設，介護，福祉 などを交えた会議体を構成し，主体的に，かつ病床 機能報告などのデー夕に基づいて科学的に体制構築 を図るという新しい方法論が導入された。また，医 療機関のみならず，医療従事者についても，地方自 治体が就労相談，あつせん，教育などに係わるべき ことが定められ，地方自治体の硬軟両面のコント ロール機能の拡充により, 医療福祉及びコミュニ ティの結びつきを強固なものとしつつ，相互の活性 化を図ろうとしているものであり，結果としてそれ は「地域包括ケアシステム」に集約されていくもの と考えられる.

さらに 2 つ目の方略として，政府は「国民の『健 康寿命』の延伸」 ${ }^{18)}$ を掲げ，2030 年のあるべき姿と して，(1)一次予防の充実，(2)医療イノベーションの 推進，(3)三次予防体制の確立を提示している。 これ を医療提供体制という立て付けから検討した場合，

a. 一次予防から三次予防までをシームレスに包 含できるプライマリケア体制（包括的医療及び 地域包括ケア体制）の構築

b. 医療のコアとなる二次予防（治療）を効率的 かつ医療提供体制にも患者にも負荷の少ない形 で実現するためのイノベーション推進

を両輪的に進めようとするものと理解できる。す なわち，この構想からは，現在の保険医療の枠組み である治療中心・現物給付型とは異なる医療パラダ イムが見えてくるのであり，特に生活圈である地域 における医療は，保健・療養・生活復帰にむけた取 り組みに軸足を移していく必要があると考えられる.

地域包括ケアシステムとは，厚生労働省によれ ば，「ニーズに応じた住宅が提供されることを基本 とした上で，生活上の安全・安心・健康を確保する ために医療や介護のみならず，福祉サービスも含め た様々な生活サービスが日常生活の場で適切に提供 できるような地域での体制」と定義19)され，地域住
民の視点からは「できる限り住み慣れた自宅や地域 で暮らし続けながら，必要に応じて医療や介護等の サービスを使い，最期を迎えられるような体制」と いうことができる.

「地域」であり「包括的ケア」という場合，地域 住民，特に高齢者に発生し得る全人的な諸問題をそ の人の「生活」レベルで評価し，検討し，解決を図 ることのできるすべてのケア（医療・介護・福祉） がシステムとして一人ひとりに向けて動員されるこ とを意味するものと考えられる。

これまでの医療や介護・福祉のそれぞれの枠組み におけるケアが相互に無関係に提供されている状況 では，無理や無駄やムラが発生し，過剩に濃厚なケ アが施される一方で，本質的に必要なケアが与えら れないという事態が発生する可能性がある。とりわ け医療などの極めて個人性の高いケア領域における 公平性や公正性とは，すべての人に同じものが与え られることではなく, 総枠規制の範囲において, 個 人の真の必要に応じて過不足のないケアが提供され ることをいうものと考えられる。とすれば，医療な どの受給者に提供されるケアの制度的連携や乗り入 れ関係の大枠を国が作り，地方自治体が具体的に構 想し，コミュニティレベルで実現されるという地域 包括ケアシステムは，たとえ，実施上多くの問題を 孕んでいたとしても，合目的性があるものと考えら れる。

加えて，低下傾向にある地域の財政や，医療資源 （人材）という現実的な制約を考えれば，現存する 制度をいかに新たなパラダイムの下で再編し，ラン ニングさせるかを考えることが優先事項となるであ ろう。 くらしの主体は地域住民個人であり，その個 人が人生を全うするには自らの医療や保健に主体的 に係わることが必要である旨,「患者参加の医療」 として医療法にも規定されている。こうした地域住 民の主体的な取り組みを「自助」とし，これら個別 の取り組みが良好に結果するためには「互助」が, そしてよりよい取り組みとなるための導きとして 「共助」が，さらに全体的取組として普及させるた めには「公助」が，現存する制度や資源の再編と運 用を支える考え方として示されていると考えられ， 医療提供側から見ても，医療受給側からみても，痛 みが伴ったとしても合理的な選択であると考えざる を得ない。 


\section{4. 爪白癬症の協働的治療の試みからみえてきた もの}

超高齢・少子化社会における地域医療の最大の命 題は，「地域住民個々人の生活価值実現の支援」で あることが制度設計上も医療の法倫理的展開からも 明確になってきた，医療提供側にとっては，従来の 1 次予防 $\rightarrow(2$ 次予防 $) \rightarrow 3$ 次予防というフローから 転じて, 患者個々人の 3 次予防をいかに質の高いも のとして実現していくか，に始まり，当該患者の新 たな段階の 1 次予防を展望する, いわば逆螺旋的展 開に向けた意識変容・行動変容を迫るものであり, 従来の医療システムに乗つた quantity 依存型のア プローチから, quality 依存型のアプローチ（Narrative Based Medicine）への転換を期すべき局面で ある. 医療の一般的効率や有益性から推しても, quality 依存型のアプローチ（Narrative Based Medicine）の特質から推しても, 専門性の高い職種 による多角的連携的アプローチが欠かすことはでき ないのは明らかである.

われわれは，今回，地域の生活部面で長期療養し ている患者の「生活の価值，質」に迫るため，爪白 癬症の治療を目指したチームアプローチを試みた。

爪白癄症は, 体力の衰えた, 衛生環境が病院並み に整備されているわけではない, 生活状況も一定で はない居宅高齢療養患者にかなりの高頻度でみられ るものの, 今津, 米田らの報告20)にある通り, 気後 れがあって言い出さない, あるいは市販の水虫治療 薬などに頼つているなど医療従事者側から見い出し 難く, 見い出せたとしても, 皮膚科専門知識を必要 とする薬物適用は難しい, 直ちに生活・生命に影響 しないなどの「理由」で，ともすれば医学的薬学的 対処を置き去りにしがちな真菌感染症である，その 一方で, 内田の報告 ${ }^{21)}$ によれば，看護師の行うフッ トケアには，明らかな状態改善効果が認められ，患 者満足度も高いとされている.

今回, 新規の外用爪白癬症治療薬を用いたチーム アプローチのために，実践者である在宅医，看護 師，薬剤師のほかに指導統括を担当する医師，アカ デミアも加わって, 総合的な検討評価を行い得る体 制を組んだ.

結果及び評価については，今津，米田の報告にあ る通りであるが, 内服薬によらなければ積極的治療 ができなかったところ，外用剤という剤型の工夫が
もたらした効果は, 治癒という測定可能なものばか りではなく，質的なレベルで大きな意義を持ったも のであったといえる，山浦による薬剤情報の収集と 分析評価 ${ }^{22)}$ をビデンスバックグラウンドとして, 「塗る」という簡便な方法による治療が保証され， 医療看視の下で患者自らが治療に参加し，その効果 を視認できることの「価值」はそのまま患者の生活 価值に転嫁できるものであった，米田の報告によれ ば，90 歳を超える余命 6 力月の患者が意欲を示す 例が複数あつたとされる. ${ }^{23)}$

また，かならずしも皮膚科に専門性があるわけで はない在宅医にとつて, 治療の必要性を認めつつ も，全身作用に対する懸念があって使用できなかつ た抗真菌薬を外用で局所的に使用できることは，当 該患者の薬物治療の組み立て全般にとって有意義で あり, 頻回の血液検査の必要を免れることも加え て, 患者・医療側の双方の負担軽減が可能になつ た。さらに，内田の報告にあるごとく，「フットケ アの有用性は認めつつも，もし，看護師のケアのみ にその負担がくる場合，相当の時間を要し，本来行 うべきケアが実施できない可能性がある」という問 題提示 ${ }^{21)}$ に対しても，一定の支援を与えることがで き, 薬剤師のバックアップの下, 協働的介入を行う ことができる可能性を示唆した。

\section{5. 地域医療のパラダイムと「薬」の貢献}

以上，今回の試みである投与薬剤の剂型変更を軸 とした新規の治療計画構築とチームによる実践が, 患者の生活価值の変化をもたらすとともに, 治療実 践上の価值まで変化させていったことを明らかにし た.

現在, 在宅長期療養者におけるもう 1 つの課題 は, 多剂併用, 長期連用である.「残薬確認」「向精 神薬の新規処方制限」などの措置により，戦術的な 適正化が進められてはいるが，既に多剂長期連用の 下で，ある種の病態の安定が得られている場合，減 薬, 断薬などに踏み切るのは容易な決断ではない.

こうした事態に対しても，今回の試みは一定の示 唆を与えるものであった，われわれは，チームによ る多角的な検討を重ね, 薬剤の適用とその評価方法 を決定し，使用に際しては患者の全身病態のチェッ クも行い, 薬物使用上の課題を抽出しつつ, 新たな 解決の方途を探ってきた。「チームによる共同的プ ロトコールの作成と協働的実施 ${ }^{24)}$ に即して PDCA 
サイクルを動かしてきたのである.

慢性期の療養の主体は薬剤(内科的関与) である. 患者の長期的療養に係わる薬剤師は, 個々の薬剤の 作用・副作用だけでなく，採用されている薬剤全体 としてどのような生理的影響があるかを評価し，患 者の生活実感を改善できるような，あるいはほかの 医療従事者にとつて有益と考えられる用法，新規薬 剤の提案，場合によっては，減薬・断薬を目指した 代替物・代替方法の提案などを行い，協働的に評価 検討を行っていくことで，定期的なプロトコール見 直しに積極的に関与することができる。ささらには， 生活環境の改善に益する諸提案 (栄養, 衛生資材等) によって患者の生活状態改善や受けている治療に応 じた生活体制づくりに貢献することができる．これ らが今後の地域医療や在宅ケアに求められる薬剂師 の貢献のありかたであり，「かかりつけ」の意味を 体現するものであろう.

\section{謝辞本シンポジウムに至る研究活動にご賛} 同・ご尽力を賜りました臨床医の諸先生，えびす英 クリニック院長松尾英男先生, 赤坂慶友クリニック 院長稲村俊明先生, 南青山ホームクリニック院長吳 行柘先生, 東京こうクリニック院長黄 舜範先生, むすび葉クリニック院長司馬清輝先生, むすび葉ク リニック渋谷院長及川武史先生，並びに訪問看護師 の諸先生，そしてフジ夕薬局，ぬなみ薬局の薬剤師 の諸先生に感謝申し上げます。

\section{利益相反＼cjkstart開示すべき利益相反はない.}

\section{REFERENCES}

1) Ministry of Land, Infrastructure and Transport. "The state and the survey of population distribution regarding population reduction society.": 〈http://www.mlit.go.jp/singikai/ kokudosin/kaikaku/jiritu/1/shiryo6-2.pdf $\rangle$, cited 16 April, 2015.

2) Osaka Prefectural Government. The Window of Self-Government, "Population reduction society, a basic municipality as it ought to be in future.": 〈http://www.pref.osaka.lg.jp/ shichoson/jichi/ichimado27-10-5.html $\rangle$, cited 23 June, 2015.

3) Statistic Bureau, Ministry of Internal Affairs and Communications. "Consumer Price Index.":〈http://www.e-stat.go.jp/SG1/estat/ List.do?bid $=000001074279 \&$ cycode $=0\rangle$, cited 25 April, 2015.

4) Ministry of Health, Labour and Welfare. "Medical expenses per person; research about the trend of medical expenses.": 〈http:// www.mhlw.go.jp / bunya / iryouhoken / data base/zenpan/iryou_doukou_b.html $>$, cited 25 April, 2015.

5) Ministry of Health, Labour and Welfare. The general situation of patients-research 2014, "The shift in the rate of treatment accepters by age series.":〈http://www.mhlw.go.jp/tou $\mathrm{kei} / \mathrm{saikin} / \mathrm{hw} / \mathrm{kanja} / 14 / \mathrm{dl} / 02 . p d f\rangle$, cited 17 August, 2015.

6) Japanese Medical and Dental Practitioners for the Improvement of Medical Care. "The shift in medical expenses (compare with 2000's) by medical phase, and by medical facility.": 〈https://hodanren.doc-net.or.jp/news/tyousa/ 171130_srh_med.pdf $\rangle$, cited 25 March, 2018.

7) Japanese Medical and Dental Practitioners for the Improvement of Medical Care. "The shift in drug and medical expenses for a medical practitioners' receipt with outpatient service.": 〈https://hodanren.doc-net.or.jp/news/ tyousa/161114_yakuzai.pdf $\rangle$, cited $25 \mathrm{March}$, 2018.

8) Kinki Regional Bureau of Health and Welfare. "The outline, the fiscal Heisei 28 revision of dispensing fee.”: 〈https://kouseikyoku.mhlw. go.jp / kinki / gyomu / gyomu / hoken_kikan / documents/28haifusiryou-yaku1-2.pdf $\rangle$, cited 25 March, 2018.

9) Miwa R., Akimoto Y., Suzuki M., Miyamoto N., Suzuki J., Fukushima N., "The Pharmaceutical Affairs Law and Related Laws," 4th revised edition, Nankodo Co., Ltd. Tokyo, 2015, pp. 385-386.

10) Ministry of Health, Labour and Welfare. Promotion of prevention activity and health management for "The society to be possible to extend people's healthy life expectancy.": 〈http://www.mhlw.go.jp/ file / 04-Houdouha ppyou-12401250-Hokenkyoku-Iryouhitekiseika taisakusuishinshitsu/0000019922.pdf $\rangle$, cited 23 July, 2015.

11) Ministry of Health, Labour and Welfare: 
〈http: // www.mhlw.go.jp / file / 04-Houdouha ppyou-12401250-Hokenkyoku-Iryouhitekiseika taisakusuishinshitsu/0000019923.pdf $\rangle$, cited 23 July, 2015.

12) National Center for Geriatorics and Gerontology, Ministry of Health, Labour and Welfare, Heisei 24 geriatric health care and health enhancement project. "Research and study to grasp home patients' food intake and their nutritional status," October 2013.

13) Suzuki J., Fukamachi N., Otsuka R., Kutsuwa M., The Yuumi Memorial Foundation for Home Health Care Research Grant Program 2014. "The influence of the drug to food intake and to nutrition status of aged patients at home," October 2015.

14) Minato-ward home palliative care study group, Kitasato University School of Pharmacy, Minato-ward home palliative care support project, “The research with the citizens' cognition regarding Palliative Care and Home Medical Care'. Annual Lecture Meeting for Minato-ward inhabitants, 5 February, 2016.

15) Prime Minister of Japan and His Cabinet, "Comprehensive Reform of Tax and Social Security," 30 November, 2012: 〈http://www. kantei.go.jp / jp / singi / kokuminkaigi / dai1 / sankousiryou3.pdf $\rangle$, cited 7 July, 2015.

16) Miwa R., Akimoto Y., Suzuki M., Miyamoto N., Suzuki J., Fukushima N., "The Pharmaceutical Affairs Law and Related Laws," 4th revised edition, Nankodo Co., Ltd., Tokyo, 2015, pp. 317-319.

17) Miwa R., Akimoto Y., Suzuki M., Miyamoto N., Suzuki J., Fukushima N., "The Phar maceutical Affairs Law and Related Laws," 4th revised edition Nankodo Co., Ltd., Tokyo, 2015 pp. 345-356.

18) Prime Minister of Japan and His Cabinet,
"Health and Mecicine Strategy," 22 July, 2014: 〈http: // www.kantei.go.jp / jp / singi / kenkouiryou / suisin / ketteisiryou / dai2 / siryou1.pdf $\rangle$, cited 22 July, 2015.

19) Ministry of Health, Labour and Welfare. "For establishment of integrated community care system," 5 March, 2015: 〈http://www. mhlw.go.jp / file / 05-Shingikai-12301000-Rou kenkyoku-Soumuka/0000078375.pdf $\rangle$, cited 7 July, 2015.

20) Imazu Y., the 136th Annual Meeting of the Pharmaceutical Society of Japan, Symposium S55, "Improving the quality of regional medical care through cooperation of doctors, nurses and pharmacists-The treatment of onychomycosis and tending to overlooked maladies," Yokohama, March 2016.

21) Uchida E., the 136th Annual Meeting of the Pharmaceutical Society of Japan, Symposium S55, "A study of home care ringworm treatment and follow up by visiting nurse and doctors-interventions and their effects," Yokohama, March 2016.

22) Yamaura K., the 136th Annual Meeting of the Pharmaceutical Society of Japan, Symposium S55, "Role of Pharmacists in onychomycosis topical therapy of patients at home," Yokohama, March 2016.

23) Yoneta Y., the 136th Annual Meeting of the Pharmaceutical Society of Japan, Symposium S55, "Current status of onychomycosis topical therapy for patients at home," Yokohama, March 2016.

24) The Chief of Health Policy Bureau, Ministry of Health, Labour and Welfare, Notification Iseihatsu 0430 Dai 1 gou "The promotion of team medical care on the medical staffs' cooperative and coordinated actions," 30 April, 2010. 